PRZEGLĄD NAUK HISTORYCZNYCH 2017, R. XVI, NR 2

http://dx.doi.org/10.18778/1644-857X.16.02.09

Miroseaw J. LeszKa

UNIWERSYTET LÓDZKI*

\title{
Bizantyńczycy w służbie władców bułgarskich w pierwszej polowie IX wieku
}

B izantyńczyków, którzy żyli w Bułgarii w pierwszej połowie wieku IX, można $z$ grubsza podzielić na tych, którzy przybyli do niej w ramach masowych przymusowych przesiedleń oraz tych, którzy znaleźli się w niej w konsekwencji własnych, indywidualnych decyzji ${ }^{1}$. W pierwszej grupie można wydzielić jeńców wojennych, którzy znaleźli się w rękach bułgarskich w wyniku działań zbrojnych oraz ludność deportowana do Bułgarii $z$ terenów zdobytych na Bizantyńczykach. Tego typu sytuacje notujemy w czasie wojen prowadzonych przez chana Kruma $z$ Niceforem I, a następnie $z$ jego następcami: Michałem I i Leonem V. Wiadomo, że spora liczba Bizantyńczyków znalazła się w rękach bułgarskich m.in. po zdobyciu Sardyki w 809 r., pogromie armii Nicefora I w lipcu 811 r. czy w konsekwencji zdobycia bizantyńskich twierdz: Deweltu, Mesembrii czy Adrianopola w latach 812-8132. Część z nich dość szybko,

* Wydział Filozoficzno-Historyczny, Instytut Historii, Katedra Historii Bizancjum, e-mail: mirleszka@poczta.onet.pl.

${ }^{1} \mathrm{Na}$ temat Bizantyńczyków w Bułgarii w interesującym mnie okresie pisali: R. Browning, Byzantines in Bulgaria - Late $8^{\text {th }}-$ Early $9^{\text {th }}$ Centuries, [w:] Studia Slavico-Byzantina et Medievalia. In memoriam Ivan Dujčev, vol. I, ed. P. Dinekov et al., Sofia 1988, s. 32-36; R. Raš ev, Vizantijcite v Bălgarija do pokrăstvaneto, [w:] Civitas divino-humana. In honorem annorum LX Georgii Bakalov, red. C. Stepanov, V. Vačkova, Sofija 2004, s. 151-162; V. Angelov, Njakolko slučaja na čuždenci begălci v Părvata Bălgarska Dăržava, „Bulgaria Mediaevalis” 2015, t. VI, s. 321-330; Y.M. Hristov, Prisoners of War in Early Medieval Bulgaria (Preliminary Remarks), „Studia Ceranea” 2015, t. V, s. 73-106.

${ }^{2} \mathrm{Na}$ temat wzmiankowanych akcji przesiedleńczych por. R. Rašev, op. cit., s. 153-154; K. S t a n ev, Deportiranite romeiv Bălgarija 812-837 godina, [w:] Ottuka 
w wyniku wymiany jeńców między cesarstwem a Bułgarią, wracała do Bizancjum. Byli jednak i tacy, którzy nie zostali wykupieni $z$ niewoli, i tacy, którym nie udało się $z$ niej uciec i stawali się już na stałe poddanymi chanów bułgarskich.

W artykule chciałbym zając się tymi Bizantyńczykami, którzy $z$ różnych powodów znaleźli się w różnym charakterze na służbie bułgarskiej. Nie była to grupa specjalnie liczna. Odnotowujemy w jej obrębie zarówno tych Bizantyńczyków, którzy osiedlili się w Bułgarii w wyniku własnych decyzji, jak i tych, którzy zostali jeńcami wojennymi czy przymusowymi przesiedleńcami.

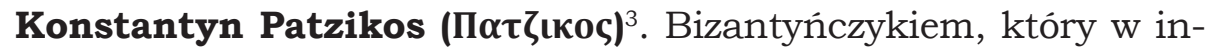
teresującym mnie okresie zrobił w Bułgarii największą karierę, był Konstantyn Patzikos. Był on mężem nieznanej $z$ imienia siostry chana Kruma. Nie wiadomo, kiedy dokładnie pojawił się w Bułgarii i z jakich powodów opuścił terytorium cesarstwa. Anonimowy autor, pisząc o wydarzeniach roku 813, stwierdził, że Konstantyn Patzikos przed wielu laty zbiegł do Bułgarii ${ }^{4}$. Biorąc pod uwage to, że w $813 \mathrm{r}$. jego syn był na tyle duży, że uczestniczył w wyprawie wojennej chana Kruma, a w czasie spotkania $z$ cesarzem Leonem $V$ powierzono mu nader odpowiedzialne zadanie pilnowania chańskiego konia, to sądzi się, że musiał mieć przynajmniej 12 lat. To $z$ kolei prowadzi do wniosku, że Konstantyn Patzikos zawarł zwiąek małżeński $z$ siostra Kruma najpóźniej ok. 800 r. ${ }^{5} \mathrm{~W}$ sytuacji, gdy tradycyjnie datuje się początki rządów Kruma na 802 lub 803 r., to ślub musiał nastapić, jeszcze zanim został on władca Bułgarii. Warto poczynić jednak pewne zastrzeżenie. Wcale nie ma pewności, że wyniesienie Kruma nastapiło we wzmiankowanym czasie. Ostatnia informacja o rządach Kardama, jego poprzednika, pochodzi z 796 r. ${ }^{6}$ Nie można więc wykluczyć, że Krum przejął władzę w nieodległym od tej daty

započva Bălgarija. Materiali ot vtorata nacjonalna konferencija po istorija, archeologija $i$ kulturen turizăm „Pătuvane kăm Bălgarija” - Šumen, 14-16.05.2010 godina, red. I. Jordanov, Šumen 2011, s. 183-196.

${ }^{3}$ Na temat Konstantyna Patzikosa por. m.in. R. Browning, op. cit., s. 34-35; R. Raš ev, op. cit., s. 155; Prosopographie der mittelbyzantinischen Zeit. I. Abteilung (641-867) [dalej: PMB], ed. F. Winkelmann et al., Bd. II, Berlin-New York 2000, s. 558-559 (3920); Y.M. Hristov, op. cit., s. 88.

4 Scriptoris Incerti Historia de Leone Bardae Armenii filio, [w:] Leonis Grammatici Chronographia, rec. I. Bekker, Bonnae 1842, s. 343 [dalej: Scriptor Incertus].

${ }^{5}$ R. Browning, op. cit., s. 35.

${ }^{6}$ M.J. Les zka, Wizerunek władców pierwszego państwa bułgarskiego w bizantyńskich źródłach pisanych (VIII - pierwsza połowa XII wieku), Łódź 2003, s. 31. 
czasie i Konstantyn zawarł zwiąek małżeński z siostrą panującego już chana. Wyraźnie wskazywałoby to na przynależność Konstantyna Patzikosa do bułgarskiej elity. Tak czy inaczej wydaje się, że Konstantyn musiał się pojawić w Bułgarii na jakiś czas przed 800 r. i pozyskać zaufanie Kardama, a później Kruma, względnie samego Kruma. Robert Browning wiązał jego pojawienie się w Bułgarii ze zwycięstwem Kardama nad wojskami bizantyńskimi pod Markellai w $792 \mathrm{r}^{7}$, ale jest to jedynie przypuszczenie niepoparte materiałem źródłowym. Nie wiemy nic o jego losach przed pojawieniem się w Bułgarii. Skoro znalazł uznanie na dworze bułgarskim, to wolno sądzić, że mógł być przedstawicielem bizantyńskiej elity i przed ucieczka do Bułgarii piastował jakiś urząd lub dowództwo wojskowe. Jego wiedza i doświadczenie stały się istotne dla Bułgarów szczególnie w czasie, gdy od 807 r. rozpocząl się etap konfrontacji między cesarstwem a Bułgaria, którego apogeum nastapiło w latach $811-814^{8}$. Konstantyn Patzikos musiał cieszyć się wyjątkowym zaufaniem Kruma, skoro ten uczynił go swoim towarzyszem podczas spotkania z Leonem V w 813 r. Oprócz niego w otoczeniu Kruma znaleźli się jedynie wzmiankowany syn Konstantyna oraz nieznany $z$ imienia Bułgar kawchan - logoteta9 ${ }^{9}$. Konstantyn zapewne podczas spotkania miał odgrywać rolę tłumacza. Jak powszechnie wiadomo, Leon V postanowił wykorzystać spotkanie do próby zamachu na Kruma. Zamach się nie powiódł, władcy bułgarskiemu udało się uciec. Konstantyn i jego syn zostali pojmani. Za swoją lojalność wobec Kruma zapewne zapłacili najwyższą cenę, choć źródła tego jednoznacznie nie stwierdzaja - informuja jedynie, że Konstantyn i jego syn znaleźli się w rękach bizantyńskich, a bułgarski logoteta został zabity na miejscu ${ }^{10}$.

7 R. Browning, op. cit., s. 35; P. So phoulis, Byzantium and Bulgaria, 775831, Leiden 2012, s. 253.

${ }^{8} \mathrm{Na}$ temat zmagań bułgarsko-bizantyńskich za czasów chana Kruma por. m.in. V.N. Zlatarski, Istorija na bălgarskata dăržava prez srednite vekove, t. I.1 (Părvo Bălgarsko Carstvo. Epocha na chuno-bălgarskoto nadmoštie), Sofija 1994, s. 247-292; P.E. Niavis, The Reign of the Byzantine Emperor Nicephorus I (AD 802-811), Athenes 1987, s. 221-254; W. Treadgold, The Byzantine Revival 780-842, Stanford 1988, s. 157-160, 168-189, 201-207; I. Božilov, V. Gjuzelev, Istorija na srednovekovna Bălgarija VII-XIV vek, Sofija 2006, s. 126-137; D. Ziemann, Vom Wandervolk zur Grosmacht. Die Entstehung Bulgariens im frühen Mittelalter (7. bis 9. Jh.), Cologne-Weimar-Vienna 2007, s. 241-288; P. So phoulis, op. cit., s. 173-264.

9 Scriptor Incertus, s. 344.

10 Scriptor Incertus, s. 344. 


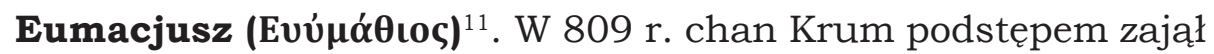
Sardykę, wymordował część mieszkańców i sześć tysięcy żołnierzy ${ }^{12}$. Nicefor I, który ruszył do Sardyki, spotkawszy grupę dowódców (archontów), którzy się uratowali, odmówił im prawa nietykalności, o które prosili, w konsekwencji czego, obawiając się o swoje życie, zdecydowali się na ucieczkę do Bułgarów ${ }^{13}$. Wśród nich był spatariusz Eumacjusz, doświadczony w sztuce mechaniki, zdolny inżynier ${ }^{14}$. O jego dalszych losach nic nie wiadomo, ale można przypuszczać, że jego umiejętności zostały wykorzystane, tak jak stało się to $\mathrm{w}$ przypadku nieznanego $\mathrm{z}$ imienia inżyniera - Araba, który, jak się zdaje, przyjął chrześcijaństwo w Bizancjum i przez czas jakiś znajdował się na bizantyńskiej służbie ${ }^{15}$. Między nim a cesarzem Niceforem doszło do konfliktu. Inżynier miał ponoć domagać się od cesarza podwyżki wynagrodzenia. Cesarz nie przychylił się do jego żądania i podobno surowo go ukarał. Wówczas arabski inżynier zdecydował się zbiec do Bułgarów. Tu zyskał uznanie u Kruma. Miał nauczyć Bułgarów budowy machin oblężniczych, które m.in. wykorzystane zostały do zdobycia Mesembrii w październiku 812 r. Nie wiemy, kiedy arabski inżynier przeszedł na służbę bułgarska poza oczywistym stwierdzeniem, że stać się to musiało podczas panowania Nicefora I i zapewne po zaostrzeniu się stosunków bizantyńsko-bułgarskich. Istnieje pogląd, że wzmiankowanego inżyniera należałoby utożsamiać $z$ Eumacjuszem ${ }^{16}$. Jednak tej hipotezy nie da się pozytywnie zweryfikować.

Leon, Bardanes, Jan, Kordyles, Grzegorz. Na służbie bułgarskiej znalazła się grupa wodzów bizantyńskich. Poza tymi, o których wspomniałem (uciekinierzy $z$ Sardyki) ${ }^{17}$, większość $z$ nich znana

${ }_{11}$ PMB I, Berlin-New York 1999, s. 532-533 (nr 1676).

12 Theophanes, Chronographia, rec. C. de Boor, vol. I, Lipsiae 1883, s. 485 [dalej: Te ofanes].

13 Te ofanes (s. 685) nie mówi wprost, że wodzowie uciekli do Bułgarii, ale $z$ kontekstu jego narracji wynika to, jak się wydaje, w sposób oczywisty - pisze bowiem, że „zbiegli do nieprzyjaciół” (tłum. A. Brzóstkowska - Testimonia najdawniejszych dziejów Słowian. Seria grecka, z. 3, wyd. A. Brzóstkowska, W. Swoboda, Warszawa 1995, s. 71); por. P.E. Niavis, op. cit., s. 233.

${ }^{14}$ Teofanes, s. 485.

15 Teofanes, s. 498; R. Browning, op. cit., s. 34; R. Raš ev, op. cit., s. 57.

${ }^{16}$ Kwestię tę analizuje V. Angelov, op. cit., s. 325; por. także P.E. Niavis, op. cit., s. 229.

17 Jakie były ich losy w Bułgarii, Teofanes co prawda nie informuje. Nie można jednak wykluczyć, że Krum, chcąc wykorzystać ich doświadczenie, zaciagnął ich na swoją służbę. 
jest jedynie $z$ inskrypcji opatrzonej przez Weselina Beszewliewa nr. 47 (z Hambarly, dziś Małamirowo ${ }^{18}$ i odnoszacej się do sytuacji z 813 lub 814 r. Znajdujemy w niej imiona greckich strategów,

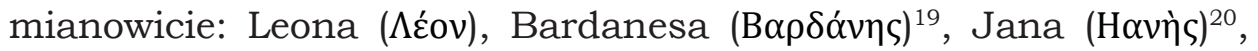

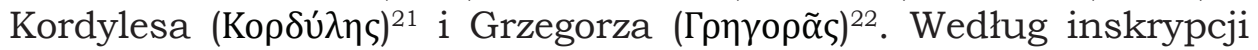
Leon (strategos) był podporzadkowany bratu Kruma, który dowodził centrum sił bułgarskich, Bardanes i Jan - iczirgu-boilasowi Tukosowi (Tzukosowi) ${ }^{23}$, dowodzacemu prawym skrzydłem, a Kordyles i Grzegorz - boilas-kawchanowi Irataisowi ${ }^{24}$. Kim byli ci strategowie? Niektórzy uczeni dopatrują się w nich tych bizantyńskich wodzów, którzy po poddaniu Sardyki w 809 r., nie mogąc liczyć na łaskę Nicefora I, uciekli do Bułgarów ${ }^{25}$. Wątpliwości co do tego zgłaszał już Robert Browning, uważając, że Krum nie powierzyłby tak ważnego militarnie zadania ludziom, którzy tak niedawno i w szczególnych okolicznościach przeszli na jego stronę ${ }^{26}$. Nie jest to argument rozstrzygajacy. Jako zdrajcy mogli się obawiać o swój los, gdyby $z$ powrotem chcieli przejść na stronę bizantyńska, a od ich dezercji do wydarzenia wzmiankowanego w inskrypcji minęły już przynajmniej cztery lata, wystarczający, jak można mniemać, czas na zyskanie zaufania bułgarskiego władcy. Część uczonych uważa, że wzmiankowani w inskrypcji wodzowie, wywodzący się z Bizancjum, przeszli na stronę bułgarska w $812 \mathrm{r}^{27}$, co wyraźnie świadczy, że nie podzielaja oni wattpliwości R. Browninga. Tak czy inaczej przy obecnym stanie źródeł nie da się rozstrzygnąć, czy uciekinierzy $z$ Sardyki i wodzowie $z$ inskrypcji $z$ Małamirowa to te same osoby.

Istnieje pogląd, że znamy późniejsze losy części wzmiankowanych $\mathrm{w}$ inskrypcji wodzów ${ }^{28}$. Leon i Jan w ostatecznym rozra-

18 V. Beš evliev, Părvobălgarski nadpisi, Sofija 1979, s. 173-174.

19 PMB I, s. 254 (nr 768).

20 PMB II, s. 322 (nr 3198).

${ }^{21}$ PMB II, s. 600-601 (nr 4060 i 4061).

22 PMB II, s. 47 (nr 2337).

${ }^{23}$ PMB V, Berlin-New York 2001, s. 67 (nr 8542).

${ }^{24}$ PMB II, s. 407 (nr 3462).

25 Przykładowo: V. B eš evliev, op. cit., s. 179.

${ }^{26}$ R. Browning, op. cit., s. 34; por. P. Sophoulis, op. cit., s. 274. Logiczna konsekwencją takiego stanowiska jest formułowanie poglądu, że wodzowie ci znaleźli się na bułgarskiej służbie jeszcze za czasów chana Kardama.

${ }^{27}$ R. Raš ev, op. cit., s. 155-156.

${ }^{28}$ V. Beš evliev, op. cit., s. 176-177; T. W a silewski, Bizancjum $i$ Słowianie w IX wieku. Studia $z$ dziejów stosunków politycznych i kulturalnych, Warszawa 1972, s. 57. 
chunku mieli się znaleźć w niełasce u chana Bułgarów i zgodnie ze świadectwem Synaksarionu Kościoła konstantynopolitańskiego stracili życie w trakcie prześladowań ludności bizantyńskiej. Stali się męczennikami za wiarę - mieli być ścięci przez Bułgarów ${ }^{29}$. Kordylesa utożsamia się $z$ Kordylasem, stratelatesem, stojącym na czele przesiedleńców bizantyńskich mieszkających nad Dunajem. To on miał w latach trzydziestych zorganizować ich powrót do ojczyzny ${ }^{30}$. Bardanes utożsamiany jest zaś $z$ Bardasem ${ }^{31}$, synem Kordylasa (tj. Kordylesa). Trzeba jednak bardzo ostrożnie podchodzić do tych identyfikacji, ponieważ opieraja się one jedynie na podobieństwie imion.

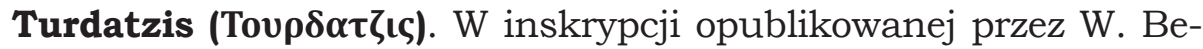
szewliewa pod nr. 66 wspomniany jest Turdatzis, kandydat i threptós ánthropos Omurtaga, który „zmarł wewnattrz”32. Według Raszo Raszewa miał on być Armeńczykiem $z$ pochodzenia i członkiem gwardii pałacowej (kandidatos) któregoś z bizantyńskich cesarzy. W nieznanych okolicznościach zbiegł do Bułgarii i podjął służbę na chańskim dworze, zmarł za panowania Omurtaga ${ }^{33}$. Trzeba zaznaczyć, że koncepcja R. Raszewa opiera się na założeniu, że imię Turdatzis jest pochodzenia armeńskiego oraz na użyciu greckiego terminu (kandidatos), co prowadzi autora do wniosku, że musiał on być najpierw na służbie bizantyńskiej i następnie $z$ niej zdezerterować. Abstrahując od etymologii imienia, które W. Beszewliew uznaje za protobułgarskie ${ }^{34}$, to użycie terminu kandidatos nie tyle oznacza, że Turdatzis kiedyś pełnił tę funkcję na dworze bizantyńskim, a raczej to, że dla autora inskrypcji, przecież napisanej po grecku, obowiązki, które spoczywały na nim na dworze bułgarskim, przynajmniej w jakimś okresie jego służby, były podobne do tych, które wypełniali bizantyńscy kandidatoi ${ }^{35}$. Poza tym mało prawdopodobne wydaje się, żeby Omurtag, z którego inicjatywy

${ }^{29}$ Synaxarium ecclesiae Constantinopolitanae, ed. H. Delahaye, Bruxelles 1902, kol. 416; R. Rašev, op. cit., s. 156; P. Sophoulis, op. cit., s. 38-39, 302-303.

$30 \mathrm{Na}$ temat tych wydarzeń por. T. W a silew ski, op. cit., s. 84-87.

31 PMB I, s. 261 (nr 79).

${ }^{32}$ V. Beševliev, op. cit., s. 221. Inskrypcja ta znaleziona została w 1970 r. w Plisce. Na temat funkcji threptós ánthropos por. M.J. Leszka, K. Marinow, Carstwo bułgarskie. Polityka, społeczeństwo, gospodarka, kultura, 866-969, Warszawa 2015, s. 218 (tam dalsza literatura).

${ }^{33}$ R. Raš ev, op. cit., s. 155.

${ }^{34}$ V. Beš evliev, op. cit., s. 222.

${ }^{35}$ Ibidem. 
powstała ta inskrypcja, chciał upamiętnić to, że Turdatzis, zanim został jego threptós ánthropos, był na którymś etapie swojego życia na bizantyńskiej służbie.

Raszew zwrócił uwagę, że część tych poddanych cesarza bizantyńskiego, którzy przechodzili na stronę bułgarska, miała pochodzenie niegreckie (głównie armeńskie), co skłoniło go do sformułowania przypuszczenia, że ten właśnie wzgląd (pochodzenie) był czynnikiem ułatwiającym dezercję. Wydaje się, że bułgarski badacz idzie zbyt daleko w swoim rozumowaniu. Abstrahujac od reprezentatywności materiału źródłowego, którym dysponujemy, i kwestii lojalności ludów zamieszkujących Bizancjum wobec Konstantynopola, trzeba zwrócić uwagę na to, że w omawianym okresie to właśnie Armeńczycy stanowili sporą część kadry dowódczej armii bizantyńskiej $^{36}$ i tylko choćby $z$ tego względu stosunkowo często mogli się stawać przedmiotem niełaski cesarskiej, a ta przecież była głównym powodem ich przechodzenia na służbę bułgarska.

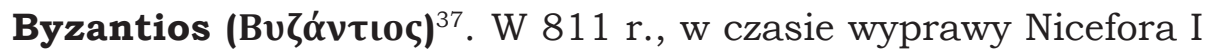
na Bułgarię, gdy armia bizantyńska obozowała pod Markellai, niejaki Byzantios uciekł do bułgarskiego władcy $z$ cesarską szatą i sporą ilością złota (100 funtów) ${ }^{38}$. Nie wiemy, jaką funkcję pełnił on w otoczeniu cesarza. Teofanes, który przedstawia tę sytuację, okre-

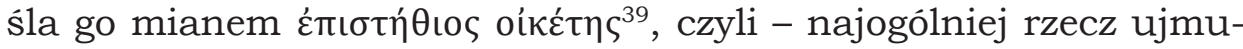
jąc - zaufanego domownika/sługi. Musiał być człowiekiem niskiego pochodzenia, choć, co słusznie zauważa R. Browning, niekoniecznie oznacza, że był niewolnikiem ${ }^{40}$. Bizantyński autor nie poinformował, $z$ jakiego powodu Byzantios zdecydował się na ucieczkę do Bułgarów. W grę, jak się wydaje, wchodzić może narażenie się na niełaskę władcy i obawa przed surową karą, względnie chęć znalezienia dla siebie lepszych warunków życia. Ta druga opcja wydaje się mniej prawdopodobna w kontekście wyprawy wojennej, która mogła się przecież zakończyć zwycięstwem bizantyńskim i podporządkowaniem Bułgarii Konstantynopolowi. Przy takim rozwoju sytuacji los

${ }^{36}$ P. Charanis, Armenians in the Byzantine Empire, „Byzantinoslavica” 1961, vol. XXII, s. 200-204; M.J. Le s zka, Uzurpacje $w$ cesarstwie bizantyńskim $w$ okresie od IV do połowy IX wieku, Łódź 1999, s. 60.

${ }^{37}$ PMB I, s. 348 (nr 1054); W. Tread gold, op. cit., s. 411; P.E. Niavis, op. cit., s. 237; P. So phoulis, op. cit., s. 19 (uważa postać Byzantiosa za fikcyjna, jednak bez podania argumentów na rzecz tego poglądu).

${ }^{38}$ Teofanes, s. 490.

39 Teofanes, s. 490.

${ }^{40}$ R. Browning, op. cit., s. 34. 
Byzantiosa - bądź co bądź zdrajcy - na pewno nie poprawiłby się, a zapewne znalazłby swój tragiczny finał. Browning sądzi, że Byzantios musiał mieć jeszcze jakiegoś towarzysza czy towarzyszy uciecz$\mathrm{ki}$, a to ze względu na ciężar złota, które ze sobą zabrał ${ }^{41}$. Nie musi to być takie oczywiste, biorac pod uwage to, że zapewne Byzantios wykorzystał do transportu juczne zwierzęta, a nie własne plecy. O tym, jak został przyjęty w Bułgarii, nic nie wiemy.

Opowieść Teofanesa o Byzantiosie powszechnie w nauce uważana jest za prawdziwa. Wydaje się jednak, że należałoby wobec niej zachować pewna dozę sceptycyzmu. Teofanes analizowana opowieść traktuje jako znak zapowiadający niepowodzenie wyprawy. „Jego ucieczkę wielu oceniało jako zły znak dla Nicefora”" ${ }^{2}$. Do tego trzeba dołączyć wrogość, która prezentuje chronograf wobec cesa$\mathrm{rza}^{43}$. Obraz Nicefora, którego opuszczaja nawet zaufani słudzy, $i$ to zabierając cesarskie szaty, $z$ pewnością służył kreowaniu jego negatywnego wizerunku. Należałoby zwrócić uwagę i na trudności, z którymi musiałby się uporać Byzantios, opuszczając obóz wojskowy i to w czasie trwania wyprawy wojennej. Nie można więc całkowicie wykluczyć, że opowieść została przez chronografa zmyślona.

Kinamon ${ }^{44}$. W jednym $z$ fragmentów dzieła zatytułowanego Historia męczeństwa piętnastu świadków z Tyberiopola ${ }^{45}$ Teofilakta, arcybiskupa Ochrydy, znajdujemy opowieść o niejakim Kinamonie, świętym mężu, człowieku znakomicie wykształconym, który znalazł się wśród mieszkańców Adrianopola przesiedlonych do Bułgarii przez Kruma. Bułgarski chan zezwolić miał na obecność Kinamona w otoczeniu Omurtaga, swego syna. Być może pełnił on funkcję jego opiekuna czy nauczyciela. Omurtag bardzo cenił i darzył sympatia Bizantyńczyka, ale przeszkadzało mu to, że był on chrześcijaninem. Kiedy został władca Bułgarii, postanowił nakłonić go do porzucenia

41 Ibidem.

${ }^{42}$ Te ofanes, s. 490 (tłum. A. Brzóstkowska - Testimonia..., s. 73).

${ }^{43}$ Na temat stosunku Teofanesa do cesarza Nicefora I por. I.S. Či ču r o v, Feofan Ispovednik - publikator, redaktor, avtor? (v svjazi so statej C. Mango), „Vizantijskij Vremennik" 1981, t. XLII, s. 82; o sposobie konstruowania przez Teofanesa wizerunku Nicefora I por. F. Tin n efeld, Kategorien der Kaiserkritik in der byzantinischen Historiographie von Prokop bis Nicetas Choniates, Münich 1971, s. 75-78.

${ }^{44} \mathrm{Na}$ temat Kinamona por. PMB II, s. 466 (nr 3647).

45 Theophylacti Achridensis Archiepiscopi Bulgarie Historia martyrii XV martyrum Tiberiupolitanorum, 29-30, ed. I.G. Iliev, Serdicae 1994 (= Grăcki Izvori za Bălgarskata Istorija, t. IX, 2). 
chrześcijaństwa. Teofilakt przytacza rozmowę odbytą między Kinamonem a Omurtagiem, będąca konsekwencja próby przeciąnnięcia tego pierwszego na stronę pogaństwa. Nalegania Omurtaga sprowokowały Kinamona do jasnego wyznania wiary, jedynej prawdziwej - chrześcijaństwa i do zdecydowanego zdeprecjonowania pogaństwa. Wypowiedź Kinamona rozgniewała Omurtaga do tego stopnia, że zacząl mu grozić torturami ${ }^{46}$, a ostatecznie kazał go uwięzić. Miał on w więzieniu, jak twierdzi hagiograf, przebywać do końca jego panowania. Za panowania Małamira, następcy Omurtaga, Kinamon znalazł się w otoczeniu Bojana-Nrawoty, brata chana. Miał on doprowadzić do nawrócenia się Nrawoty na chrześcijaństwo, za co ten skazany został przez Małamira na śmierć. Taki sam los stał się zapewne udziałem Kinamona, choć w źródłach takiej informacji nie znajdziemy ${ }^{47}$.

Przytoczona przez Teofilakta opowieść o Kinamonie, świętym mężu - który nie dość, że nie wyrzekł się swojej wiary, przebywając przez lata na dworze bułgarskich władców, to jeszcze przyciagną do niej członka chańskiego rodu $-z$ pewnością w wielu szczegółach daleka jest od prawdy. Natomiast w kontekście tematu mojego artykułu stanowić może świadectwo tego, że w otoczeniu bułgarskich władców mogli znajdować się i znajdowali Bizantyńczycy, którzy po prostu z jakichś względów cieszyli się ich poważaniem.

$$
* * *
$$

Przedstawione postaci wyczerpuja listę Bizantyńczyków, którzy w pierwszej połowie IX w. znaleźli się (lub mogli się znaleźć) w kręgach bułgarskiej elity, w bezpośredniej styczności z chańskim

46 Theophylacti Achridensis Archiepiscopi Bulgarie Historia..., 30.

47 Nader skapa baza źródłowa nie pozwala na stwierdzenie, czy rzeczywiście jedynym powodem śmierci Bojana-Nrawoty było porzucenie pogańskiej religii, czy może też była ona przynajmniej w jakimś stopniu następstwem walk o bułgarski tron. Na to może wskazywać odsunięcie od bezpośredniego następstwa po Omurtagu nie tylko Bojana-Nrawoty, lecz także Zwinicy (Presjana?). Bez względu na to, jakie były rzeczywiste powody usunięcia Nrawoty, to stał się on pierwszym bułgarskim, chrześcijańskim męczennikiem. Por. P. Georgiev, Măčeničeskijat kult kăm Enravota: kriticizăm, chiperkriticizăm i realnost, „Godišnik na Sofijskija Universitet. Naučen centăr za slavjano-vizantijski proučvanija 'Ivan Dujčev'” 2001, t. XCI (X), s. 79-91; M.J. Leszka, Wizerunek władców..., s. 60, 70-71; Ja. Christov, Bjalo pole $v$ rannata bălgarska agiografija. Enravota, Svetecmăčenik ili obeznasleden princ, „Minalo” 2007, t. XIV.1, s. 33-37; D. Zi e m a n n, op. cit., s. 348. 
dworem $^{48}$. O ile $z$ pewnościa stanowia oni jedynie drobną część tych spośród poddanych bizantyńskiego cesarza, którzy w interesującym mnie okresie znaleźli się w Bułgarii, o tyle wydaje się, że ich przypadki maja charakter wyjątkowy, sporadyczny.

Mimo skromności dostępnego materiału źródłowego warto pokusić się o kilka wniosków. Jeśli chodzi o powody indywidualnych decyzji o osiedleniu się w Bułgarii, to przede wszystkim były one konsekwencja konfliktu $z$ cesarzem i chęcią uniknięcia - przez opuszczenie Bizancjum - kary z jego strony. Wydaje się, że bizantyńskim emigrantom jedynie $\mathrm{w}$ sporadycznych przypadkach udawało się wtopić w bułgarskie społeczeństwo, jak stało się to w przypadku Konstantyna Patzikosa. Tym, co utrudniało im adaptację w bułgarskim społeczeństwie, $z$ pewnością $\mathrm{w}$ tym okresie była religia. Bez wyrzeczenia się chrześcijaństwa pozostawali obcymi. Do tego oczywiście dołączyć należy kwestie językowe. Bizantyńscy uciekinierzy być może liczyli również na to, że w przyszłości, np. w wyniku zmiany na tronie, będa mogli powrócić do siebie. Nie bez znaczenia było $i$ to, że chan i jego otoczenie $z$ dozą podejrzliwości musieli traktować bizantyńskich uciekinierów. Szczególnie w czasie, kiedy dochodziło do zmagań zbrojnych między Bułgaria a Bizancjum. Stracenie dwóch bizantyńskich wodzów po tym, jak przez pewien czas byli na bułgarskiej służbie, świadczy o tym w sposób nader wyraźny.

Bułgarzy potrafili wykorzystać umiejętności i wiedzę Bizantyńczyków do własnych celów, np. do udoskonalenia swojej sztuki wojennej - przykładem są bizantyńscy inżynierowie, którzy nauczyli ich budowy machin oblężniczych.

\section{Bibliografia}

\section{$\dot{Z}_{\text {RÓDEA DRUKOWANE }}$}

Beševliev V., Părvobălgarski nadpisi, Sofija 1979.

Scriptoris Incerti Historia de Leone Bardae Armenii filio, [w:] Leonis Grammatici Chronographia, rec. I. Bekker, Bonnae 1842.

Synaxarium ecclesiae Constantinopolitanae, ed. H. Delahaye, Bruxelles 1902.

Testimonia najdawniejszych dziejów Słowian. Seria grecka, z. 3, wyd. A. Brzóstkowska, W. Swoboda, Warszawa 1995.

${ }^{48}$ Listę uchwytnych w źródłach Bizantyńczyków, którzy znaleźli się w Bułgarii przed przyjęciem chrztu, podaje R. Rašev, op. cit., s. 155-160. 
Theophanes, Chronographia, rec. C. de Boor, vol. I, Lipsiae 1883.

Theophylacti Achridensis Archiepiscopi Bulgarie Historia martyrii XV martyrum Tiberiupolitanorum, ed. I.G. Iliev, Serdicae 1994 (= Grăcki Izvori za Bălgarskata Istorija, t. IX, 2), 42-79.

\section{OpRacowania}

Angelov V., Njakolko slučaja na čuždenci begălci v Părvata Bălgarska Dăržava, „Bulgaria Mediaevalis” 2015, t. VI, s. 321-330.

Božilov I., Gjuzelev V., Istorija na srednovekovna Bălgarija VII-XIV vek, Sofija 2006.

Browning R., Byzantines in Bulgaria - Late $8^{\text {th }}$-Early $9^{\text {th }}$ Centuries, [w:] Studia Slavico-Byzantina et Medievalia. In memoriam Ivan Dujčev, vol. I, ed. P. Dinekov et al., Sofia 1988, s. 32-36.

Charanis P., Armenians in the Byzantine Empire, „Byzantinoslavica” 1961, vol. XXII, s. 200-204.

Christov Ja., Bjalo pole v rannata bălgarska agiografija. Enravota, Svetec-măčenik ili obeznasleden princ, „Minalo” 2007, t. XIV.1, s. 33-37.

Christov Ja. [Hristov Y.M.], Prisoners of War in Early Medieval Bulgaria (Preliminary Remarks), „Studia Ceranea” 2015, t. V, s. 73-106.

Čičurov I.S., Feofan Ispovednik - publikator, redaktor, avtor? (v sujazi so statej C. Mango), „Vizantijskij Vremennik” 1981, t. XLII, s. 78-87.

Georgiev P., Măčeničeskijat kult kăm Enravota: kriticizăm, chiperkriticizăm i realnost, „Godišnik na Sofijskija Universitet. Naučen centăr za slavjano-vizantijski proučvanija 'Ivan Dujčev"' 2001, t. XCI (X), s. 79-91.

Leszka M.J., Uzurpacje $w$ cesarstwie bizantyńskim $w$ okresie od IV do połowy IX wieku, Łódź 1999.

Leszka M.J., Wizerunek władców pierwszego państwa bułgarskiego $w$ bizantyńskich źródłach pisanych (VIII - pierwsza połowa XII wieku), Łódż 2003.

Leszka M.J., Marinow K., Carstwo bułgarskie. Polityka, społeczeństwo, gospodarka, kultura, 866-969, Warszawa 2015.

Niavis P.E., The Reign of the Byzantine Emperor Nicephorus I (AD 802-811), Athenes 1987.

Prosopographie der mittelbyzantinischen Zeit. I. Abteilung (641-867), Bd. I, II, V, ed. F. Winkelmann et al., Berlin-New York 1999, 2000, 2001.

Rašev R., Vizantijcite v Bălgarija do pokrăstvaneto, [w:] Civitas divino-humana. In honorem annorum LX Georgii Bakalov, red. C. Stepanov, V. Vačkova, Sofija 2004, s. 151-162.

Sophoulis P., Byzantium and Bulgaria, 775-831, Leiden 2012.

Stanev K., Deportiranite romei v Bălgarija 812-837 godina, [w:] Ottuka započva Bălgarija. Materiali ot vtorata nacjonalna konferencija po istorija, archeologija $i$ kulturen turizăm „Pătuvane kăm Bălgarija” - Šumen, 14-16.05.2010 godina, red. I. Jordanov, Šumen 2011, s. 183-196.

Tinnefeld F., Kategorien der Kaiserkritik in der byzantinischen Historiographie von Prokop bis Nicetas Choniates, Münich 1971. 
Treadgold W., The Byzantine Revival 780-842, Stanford 1988.

Wasilewski T., Bizancjum i Słowianie w IX wieku. Studia z dziejów stosunków politycznych i kulturalnych, Warszawa 1972.

Ziemann D., Vom Wandervolk zur Grosmacht. Die Entstehung Bulgariens im frühen Mittelalter (7. bis 9. Jh.), Cologne-Weimar-Vienna 2007.

Zlatarski V.N., Istorija na bălgarskata dăržava prez srednite vekove, t. I.1 (Părvo Bălgarsko Carstvo. Ot slavjanizacijata na dăržavata do padaneto na Părvoto Carstvo), Sofija 1927. 